Hj. Desmawaty Romli et.al, Kewenangan Kepala Desa Dalam Menyelesaikan Sengketa Masyarakat Berdasarkan Undang-Undang Desa, Halaman 17- 30

\title{
KEWENANGAN KEPALA DESA DALAM MENYELESAIKAN SENGKETA MASYARAKAT BERDASARKAN UNDANG-UNDANG DESA
}

\author{
Hj. Desmawaty Romli, ${ }^{1}$ Junaidi, ${ }^{2}$ M. Martindo Merta $^{3}$ \\ ${ }^{1}$ Fakultas Hukum, Universitas Sjakhyakirti \\ E-mail : romlidesmawati@yahoo.com \\ ${ }^{2}$ Fakultas Hukum, Universitas Sjakhyakirti \\ E-mail: junaidievy@yahoo.com, \\ Fakultas Hukum Universitas Sjakhyakirti \\ E-mail: tindotindo531@gmail.com
}

\begin{abstract}
Public activities are never separated from social communication. Village community groups adhere to the characteristics of a peaceful and serene life, it cannot be separated from differences of opinion. Conflict issues that arise are triggered by conflicts of interest that cause debate. If this is allowed, it will damage the value of decency, social values that cause disturbances in the security and comfort of the village community. The application of dispute resolution or violence in Indonesia, culturally, uses a lot of local community structures. To maintain harmony, organize and improve life in the village, it is more important to prioritize solving problems by consensus around people where there is a conflict, it is carried out peacefully. Ending the problem that was carried out by deliberation and consensus was carried out to maintain a harmonious life as the duty of the Village Head to resolve conflicts among its citizens. The authority of the Village Head to be able to resolve customary cases in examining and adjudicating according to their customs and not by law. The village head's obligation does not cancel the wishes of several individuals if they wish to have their case resolved in court, where it has been determined that the village head's obligations are to carry out his duties in resolving every community conflict in his village. The role of the Village Head as a conflict resolution issuer is very much needed to create a working judiciary in Indonesia. Conflict resolution based on local wisdom as explained in the Town Law can be utilized as much as possible in an effort to realize justice for the community.
\end{abstract}

Key words: Authority of the town head; debate goal; town law.

\begin{abstract}
Abstrak
Dalam aktivitas publik tidak pernah lepas dari komunikasi sosial. Kelompok masyarakat desa yang benar-benar memegang teguh sifat-sifat kehidupan yang damai dan tenteram, tidak dapat dipisahkan dari perbedaan pendapat. Permasalahan konflik yang muncul dipicu oleh benturan kepentingan yang menimbulkan perdebatan. Jika hal ini dibiarkan, akan merusak nilai kesopanan, nilai sosial yang menyebabkan gangguan keamanan dan kenyamanan lingkungan masyarakat desa. Penerapan penyelesaian konflik sengketa atau kekerasan di Indonesia, secara kebudayaan banyak menggunakan tatanan lokal masyarakat. Untuk menjaga keharmonisan, menata dan memperbaiki kehidupan di desa lebih mengutamakan penyelesaian permasalahan secara musyawarah mufakat disekitar orang dimana sedang berkonflik dilakukan dengan tentram. Mengakhiri permasalah yang dilakukan dengan musyawarah mufakat ini dilakukan untuk mempertahankan kehidupan harmonis. Untuk itu merupakan tugas mendasar Kepala Desa dalam menyelesaikan konflik di antara warganya. Kewenangan Kepala Desa untuk dapat menyelesaikan perkara adat dalam memeriksa serta diadili dengan adatnya tidak dengan hukum. Kewajiban Kepala Desa tersebut tidakla mengurungkan keinginan beberapa individu apabila berkehendak dalam penyelesaian perkaranya dilakukan di Pengadilan, dimana telah ditentukan mengenai kewajiban Kepala Desa agar melaksanakan tugasnya dalam menyelesaikan setiap konflik masyarakat di desanya. Peranan Kepala Desa sebagai penyelesai konflik permasalahan sangat diperlukan untuk menciptakan bekerjanya peradilan di Indonesia.
\end{abstract}


Hj. Desmawaty Romli et.al, Kewenangan Kepala Desa Dalam Menyelesaikan Sengketa Masyarakat Berdasarkan Undang-Undang Desa, Halaman 17- 30

Penyelesaian konflik yang berbasis kearifan lokal sebagaimana telah dijelaskan UndangUndang Desa dapat didayagunakan sebesarnya dalam usaha mewujudkan keadilan bagi masyarakat.

Kata kunci: Otoritas Kepala Desa, Penyelesaian Sengketa, Hukum Desa

\section{PENDAHULUAN}

Desa adalah unit wilayah lokal yang sah yang memiliki wilayah tertentu dan memiliki posisi untuk mengarahkan dan menangani administrasinya sendiri, masalah wilayahnya yang diselesaikan tergantung pada hak-hak konvensional dan tambahan standar yang dianggap dan dianggap dalam otoritas publik Republik dari Indonesia.

Sejumlah besar pada kenyataannya tinggal di daerah pedesaan. Hubungan individu yang tinggal di pedesaan diikat dengan adanya kesamaan dan solidaritas dalam kehidupan sosial masyarakat yang bersifat homogen. Kehidupan di desa adalah masyarakat yang rukun dan bersahabat atau biasa disebut sebagai daerah setempat (gemeinschaft). Pada tingkat dasar, wilayah desa memiliki atribut khusus termasuk memiliki kehidupan dan pengalaman yang tenang, tenteram dengan penghuni individu, memiliki koneksi yang nyaman dan rasa solidaritas, sehingga mereka saling mengenal dan saling membantu dalam kehidupan masingmasing yang didasari oleh sikap toleransi musyawarah. ${ }^{1}$

Keberadaan kawasan desa, yang secara sosial bekerja sama di antara warga desa sebenarnya, tidak pernah lepas dari persoalan kehidupan, persoalan yang sering terjadi dan dihadapi antara lain persoalan bentrokan, perdebatan, dan berbagai aktivitas yang dapat mengganggu ketertiban dan keamanan masyarakat desa. Permasalahan konflik kelompok masyarakat desa dapat pelanggaran kehormatan, nilai sosial dan berbagai elemen kehidupan sehingga mempengaruhi kenyamanan dan ketenangan penduduk desa tersebut. Manusia adalah makhluk konfliktis (homo konflikus) yang terus-menerus terlibat dengan kontras, bentrokan dan persaingan dengan cara sukarela ataupun terpaksa.

Menurut Soerjono Soekanto, sebab-sebab atau dasar-dasar pertentangan itu antara lain: ${ }^{2}$

${ }^{1}$ Darsono Wisadirana, Sosiologi Pedesaan Kajian Kultural dan Struktural Masyarakat Pedesaan (Malang: UMM Press, 2005). 
Hj. Desmawaty Romli et.al, Kewenangan Kepala Desa Dalam Menyelesaikan Sengketa Masyarakat Berdasarkan Undang-Undang Desa, Halaman 17- 30

1. Perbedaan karekter penduduk

Perselisihan ini terjadi karena konflik kontras dalam standar, mentalitas dan sentimen di antara mereka.

2. Perbedaan kebudayaan

Jaringan yang hidup berinteraksi dan berbaur, tradisi atau masyarakat yang berbeda bergabung satu sama lain, dengan cara ini memengaruhi kecenderungan individu untuk bergaul dalam aktivitas publik.

3. Perbedaan kepentingan

Kepentingan individu setiap individu beragam dalam kerjasamanya, baik itu moneter, politik, dll sehingga dapat memicu bentrokan.

4. Perubahan sosial

Perubahan ramah yang sangat cepat dan kecenderungan penyesuaian jangka waktu yang singkat, menghasilkan pertemuan khusus yang memiliki kontras dalam hidup mereka.

Timbulnya konflik yang terjadi dalam kehidupan sosial bermasyarakat di desa, hal ini menuntut adanya solusi dalam mengatasi permasalahan yang

2 Soerjono Soekanto, Sosiologi Suatu Pengantar (Jakarta: PT. Raja Grafindo Persada, 2006). terjadi agar dapat diselesaikan dalam waktu yang sesingkatnya untuk menciptakan rasa aman dan kenyamanan dalam masyarakat desa itu sendiri. Dituntut kemampuan dan kapabilitas terhadap permasalahan bentrokan yang terjadi di wilayah pedesaan setempat, jelasterletak pada Pundak Kepala Desa. Apabila terjadi konflik permasalahan masyarakat desa idealnya yang bertindak terlebih dahulu adalah Kades sebagai delegasi atau perantara dalam menangani masalah apa pun yang terjadi.

Pasal 26 ayat (4) huruf k Undang-Undang Nomor 6 Tahun 2014 tentang Pedesaan mengatur bahwa Kades wajib menyelesaikan perdebatan daerah di Pedesaan. Untuk mengekang kapasitas Kades sebagai tujuan debat, maka Pasal 28 Undang-Undang Nomor 6 Tahun 2014 tentang Pedesaan dikuatkan tentang pengesahan, khususnya:

(1) Kepala Pedesaan yang tidak memenuhi kewajiban sebagaimana dimaksud dalam Pasal 26 ayat (4) dan Pasal 27 bergantung pada persetujuan regulator baik sebagai pemberitahuan lisan maupun pemberitahuan tertulis.

(2) Karena persetujuan otoritatif sebagaimana disinggung dalam ayat (1) tidak dilakukan, penghentian sementara selesai dan dapat dilanjutkan dengan akhir. 
Hj. Desmawaty Romli et.al, Kewenangan Kepala Desa Dalam Menyelesaikan Sengketa Masyarakat Berdasarkan Undang-Undang Desa, Halaman 17- 30

Pentingnya kapasitas dan fungsi

Kepala desa dalam menyelesaikan konflik yang terjadi diantara warganya. Dalam membekali Kepala desa dengan kapasitas untuk penyelesaian konflik/bentrokan antara warganya, diperlukan kapasitas sebagai mediator, oleh karena itu diadakan diperlukan Pendidikan dan Pelatihan Kepala Desa. Tujuannya adalah untuk dapat diselesaikan dengan cepat, hal ini akan memperkuat rasa persatuan daerah yang telah ditegaskan dalam UndangUndang Desa. Penyelesaian konflik oleh Kepala Desa tidak dilakukan secara langsung dan tanpa penawaran atau dalam hal apa pun, berbeda halnya apabila diupayakan melalui litigasi. ${ }^{3}$

$$
\text { Dalam kehidupan }
$$

bermasyarakat yang penuh dengan rasa kekeluargaan dan persaudaraan, dimana memiliki hubungan yang sangat erat dan rasa persatuan serta saling tolong menolong dalam segala hal didasarkan pada musyawarah untuk mufakat. Berdasarkan hal ini seharusnya setiap konflik sengketa

3 Moh. Jamin, Anti Mayastuti, Mulyanto "Pemberdayaan Fungsi Kepala Desa sebagai Mediator Penyelesaian Sengketa Pasca Undang-Undang Nomor 6 Tahun 2014 tentang Desa", Jurnal Parental Hukum dan Budaya, Volume 3 Nomor 2, Oktober 2015: 55 yang terjadi dapat diselesaikan secara musyawarah, tidak seharusnya sampai di pengadilan. Sebagai warga desa yang memiliki rasa kerukunan dan persaudaraan dalam penyelesaian sengketanya dapat dilaksanakan dengan cara yang damai.

\section{METODE PENELITIAN}

Metode penelitian adalah suatu kegiatan yang dilakukan dalam melakukan suatu tindakan atau tujuan yang ingin dicapai ${ }^{4}$. Jenis eksplorasi yang diterapkan dalam penyusunan makalah logis ini adalah yuridis normatif, khususnya penilaian unik yang dilakukan berpusat pada pemeriksaan penggunaan aturan atau standar dalam hukum positif. ${ }^{5}$

Metodologi yang digunakan adalah pendekatan aturan, dilakukan dengan menggali semua hukum dan pedoman yang diidentifikasi dengan masalah yang sah yang sedang ditangani. ${ }^{6}$

\footnotetext{
${ }^{4}$ Wiryono Surachmand, Pengantar Penelitian Ilmiah (Bandung : Tarsio, 1991).

${ }^{5}$ Jhoni Ibrahim, Teori \& Metode Penelitian Hukum Normatif (Malang : Bayu Media, 2005). ${ }^{6}$ Peter Mahmud, Penelitian Hukum (Jakarta : Kencana Pradana Media Grup, 2008).
} 
Hj. Desmawaty Romli et.al, Kewenangan Kepala Desa Dalam Menyelesaikan Sengketa Masyarakat Berdasarkan Undang-Undang Desa, Halaman 17- 30

PEMBAHASAN

A. Kewenangan Kepala Desa dalam Menyelesaikan

Perselisihan

Masyarakat berdasarkan

Undang-Undang Nomor 6 Tahun

\section{4 tentang Desa}

Kades adalah komponen

penting dalam pemerintahan pedesaan dan merupakan individu utama yang menerima posisi berpengaruh di pedesaannya. Di sinilah Kades memiliki kewajiban dan komitmen untuk dapat menerima dan menyelesaikan semua konflik yang terjadi dalam masyarakat desa. Mengingat beban tugas yang berat selaku Kepala Desa sehingga dituntut memiliki kemampuan yang tangguh dalam melaksanakan kewajibannya.

Penyelesaian sengketa yang biasa digunakan adalah: ${ }^{7}$

a. Konsiliasi (perdamaian) merupakan mekanisme dalam penyelesaian sengketa dengan mempertemukan para pihak yang berkonflik untuk mencapai kata sepakat bersama menuju perdamaian;

b. Mediasi merupakan salah satu cara dalam menyelesaikan permasalahan

7 Bambang Sugeng, Penanganan Konflik Sosial (Bandung: Pusat Bencana dan Pengungsi (PUSKASI) STKS, 2011). dengan menggunakan seorang penghubung/perantara (mediator);

c. Arbitrase merupakan suatu sistem penyelesaian sengketa melalui pengadilan dengan otoritas yang ditunjuk (wasit) yang bertindak sebagai pemimpin; dan

d. Koersi adalah sistem penyelesaian sengketa memanfaatkan paksaan fisik atau mental.

Kades didalam menjalankan tugas dan kewajibannya memiliki kewenangan sebagai berikut:

1) Melakukan penyelesaian dalam tindakan urusan pertanahan, dikarenakan tanah memiliki hubungan yang sangat erat dengan kemitraan (perkumpulan manusia) yang menguasai tanah;

2) Sebagai penyelenggara hukum yang berperan dalam mencegah terjadinya pelanggaran hukum sehingga hukum dapat dijalankan sebagaimana mestinya;

3) Penyelenggara hukum dalam upaya pemulihan hukum apabila hukum tersebut telah dilanggar.

Kepala Desa dalam menciptakan rasa aman dan tertib di masyarakat desa sesuai denga napa yang dikehendaki oleh Pemerintah, sehingga tidak semua konflik yang 
Hj. Desmawaty Romli et.al, Kewenangan Kepala Desa Dalam Menyelesaikan Sengketa Masyarakat Berdasarkan Undang-Undang Desa, Halaman 17- 30

terjadi harus diselesaikan di pengadilan disebabkan adanya perkara konflik yang dapat diselesaikan oleh hakim perdamaian desa. Peranan kepala desa yang penting mengenai pelaksanaan pekerjaan di lapangan (represieve rechtsorg) yaitu sebagai hakim perdamaian desa (dordsjustitie). Jika terjadi sengketa warga masyarakat desa dan adanya tindakan-tindakan sebagai lawan dari hukum baku, kades berperan untuk membangun kembali kerukunan standar, menjaga keseimbangan di pedesaan dan menegakkan kembali hukum (rechtsherstel).

Kewajiban Kepala Desa Dalam penyelesaian bentrokan antar warga, diatur dalam Pasal 26 ayat (4) UndangUndang Nomor 6 Tahun 2014, yang menyatakan bahwa :

(4) Dalam melakukan usaha sebagaimana dimaksud pada ayat (1), kades wajib:

a. memelihara dan mengamalkan Pancasila, melaksanakan Undang-Undang Dasar Negara Republik Indonesia Tahun 1945, serta menjaga dan menjaga tegaknya Negara Kesatuan Republik Indonesia dan Bhineka Tunggal Ika;

b. mengerjakan bantuan pemerintah kelompok masyarakat pedesaan; c. menjaga kerukunan dan kendali dalam kelompok masyarakat pedesaan;

d. setuju dengan dan menerapkan hukum dan pedoman;

e. melaksanakan kehidupan berdasarkan suara dan seks yang adil;

f. melaksanakan standar Pemerintahan pedesaan yang bertanggung jawab, lugas, cakap, layak dan efektif, sempurna dan bebas dari persekongkolan, pencemaran nama baik, dan nepotisme;

g. mengatur kolaborasi dan koordinasi dengan semua mitra pedesaan;

h. mengatur organisasi Pemerintah pedesaan besar;

i. mengawasi dana dan sumber daya pedesaan;

j. menyelesaikan urusan pemerintahan yang menjadi kewenangan pedesaan;

k. menyelesaikan perdebatan daerah lokal di pedesaan;

1. membina perekonomian daerah pedesaan;

m. menumbuhkan dan menyelamatkan kualitas sosialsosial kelompok masyarakat pedesaan;

n. memungkinkan area lokal dan fondasi area lokal di pedesaan;

o. menumbuhkan kemampuan aset reguler dan menjaga iklim;

p. berikan data ke area lokal pedesaan.

Komitmen Kades perihal menyelesaikan konflik penduduk di desa, harus adanya suatu gagasan kades bertindak selaku pencegah konflik di desa. Problematika konflik ini tidak 
Hj. Desmawaty Romli et.al, Kewenangan Kepala Desa Dalam Menyelesaikan Sengketa Masyarakat Berdasarkan Undang-Undang Desa, Halaman 17- 30

hanya sebatas dalam hubungan ikatan hukum keperdataan, namun juga dapat dilihat dari berbagai aturan hukum lainnya ${ }^{8}$. Kepala desa memegang peranan sebagai hakim perdamaian untuk masyarakat desa dalam upayanya membuat sarana hukum yang mengatur hak-hak istimewa dan komitmen warga dalam melakukan kebebasan dan komitmen tersebut secara akurat dan tepat. Hukum juga memiliki fungsi sebagai instrumen yang melindungi subjek hukum itu sendiri.

\section{Pelaksanaan Undang-Undang}

Nomor 6 Tahun 2014 tentang pedesaan diarahkan dalam Undang-Undang Nomor 43 Tahun 2014 tentang Pelaksanaan Undang-Undang Nomor 6 Tahun 2014 tentang Kependudukan, yang sedikit banyak menjelaskan perbedaan ruang perkara/bentrokan, instrumen, struktur, barang. terjadi karena pilihan hanya sebagai hasil yang sah dari alasan kompromi oleh Kepala pedesaan. Sementara itu, aturan administrasi otoritas publik tidak menentukan apakah kepala pedesaan bertindak sebagai hakim pedesaan atau sebagai arbiter seperti dalam Elective

\footnotetext{
8 Samuel Dharma Putra Nainggolan, "Kedudukan Kepala Desa sebagai Hakim Perdamaian," Jurnal UBELAJ, Volume 3 Nomor 1, April 2018: 59
}

Question Goal. Jika untuk keadaan ini ia berjalan sebagai perantara, ia dapat mengacu pada Undang-Undang Nomor 30 Tahun 1999 tentang Intervensi dan Tujuan Pertanyaan Pilihan, seperti halnya Undang-Undang Nomor 48 Tahun 2009 tentang Kekuasaan Hukum. Dalam kedudukannya sebagai hakim pedesaan, upaya penyelesaian perkara/bentrokan dengan lancar pernah dikuasai pada masa Hindia Belanda yang disebut Pengadilan pedesaan (dorpsjustitie) dalam Pasal 3a RO yang tidak dicabut. ${ }^{9}$

Pasal 3a menyatakan bahwa para petinggi bertindak sebagai hakim kerukunan desa (dorpsjustitie), misalnya dalam hal terjadi pertikaian antara penduduk desa, dalam hal ada kegiatan yang bertentangan dengan hukum adat, para petinggi itu bertindak untuk menegakkan kembali kerukunan di alam desa untuk menegakkan hukum. (rechtsherstel). ${ }^{10}$

Rachmadi Usman mengatakan, seorang kepala pedesaan tidak hanya dipercaya untuk menangani urusan pemerintah, tetapi juga dibagikan dengan menyelesaikan perdebatan yang muncul di wilayah hukum standarnya.

\footnotetext{
${ }^{9}$ Samuel Dharma Putra Nainggolan

${ }^{10}$ Samuel Dharma Putra Nainggolan
} 
Hj. Desmawaty Romli et.al, Kewenangan Kepala Desa Dalam Menyelesaikan Sengketa Masyarakat Berdasarkan Undang-Undang Desa, Halaman 17- 30

Pada akhirnya, kepala desa melaksanakan tugasnya sebagai hakim perdamaian desa (dorpsjuttie). Untuk alasan ini dia akan mencoba, hal-hal berikut ini: ${ }^{11}$

a. menerima dan memeriksa semua laporan keberatan yang diajukan kepadanya.

b. Meminta otoritas pedesaan atau kepala vila untuk menyelidiki kasus ini, dengan mengunjungi pertemuan yang dimaksud dalam laporan.

c. Menyelenggarakan tentukan juga jam penyisihan dan areanya di lobi pedesaan.

d. Menyambut para senior pedesaan yang akan pergi dengan kepala pedesaan untuk mengarahkan pendahuluan, dan orang-orang penting lainnya.

e. Menghadirkan pertemuan hingga pertengkaran, saksi dengan tujuan agar pernyataan mereka dapat didengar.

f. Pembukaan pertemuan dan rekonsiliasi antar pertemuan, bila dianggap penting, dapat diselesaikan secara pribadi.

11 Rachmadi Usman, Pilihan Penyelesaian Sengketa di Luar Pengadilan (Bandung: PT. Citra Aditya Bakti, 2003). g. Lihat kasus, perhatikan penjelasan saksi, penilaian sesepuh pedesaan, pucuk desa yang bersangkutan dan lain-lain.

h. Pertimbangkan \& tentukan pilihan tergantung pada persetujuan para pihak.

i. Strategi penyelesaian konflik oleh kepala pedesaan sebagai kepala pedesaan dan sebagai hakim kerukunan pedesaan, misalnya, "perjalanan antara" di mana kepala pedesaan bertindak sebagai pihak yang tidak memihak yang membantu dua pertemuan yang bentrok dalam tujuan kompromi yang diselesaikan melalui pertimbangan untuk mencapai kesepakatan . Untuk keadaan saat ini kepala pedesaan tidak memiliki kemampuan untuk memilih. Kepala pedesaan hanya membantu pertemuan yang bentrok dalam mengamati jawaban yang memuaskan pertemuan.

Strategi yang dilakukan dalam penyelesaian permasalahan dinatara para penduduk dapat dilakukan melalui hukum adat yang berasaskan kerukunan, kepatutan dan keselarasan. 
Hj. Desmawaty Romli et.al, Kewenangan Kepala Desa Dalam Menyelesaikan Sengketa Masyarakat Berdasarkan Undang-Undang Desa, Halaman 17- 30

Hal ini dapat dijelaskan sebagai berikut: ${ }^{12}$

a. Asas Rukun

Menurut istilah adat hukum, rukun merupakan suatu kaidah dimana berfungsi yang mengisi sebagai kaidah-kaidah dalam penyelesaian sengketa adat. Standar keserasian adalah pedoman yang substansinya secara tegas diidentikkan dengan cara pandang hidup masing-masing dalam iklim yang satu dengan yang lain, untuk mewujudkan masyarakat yang aman, tenteram, dan sejahtera., dan pengakuan koneksi yang menyenangkan di antara warga desa.

b. Asas Patut

Patut adalah kesepakatan yang menyinggung gagasan keadilan dan penilaian yang baik, yang ditujukan untuk menilai suatu peristiwa sebagai demonstrasi atau keadaan manusia. Pendekatan asas patut harus dapat menyelesaikan sengketa adat dengan tetap mengikuti nama besar masingmasing pihak, jadi tidak ada yang merasa status dan kehormatannya diremehkan atau diremehkan.

12 I Nyoman Sirtha, Aspek Hukum dalam Konflik Adat di Bali (Bali: Udayana University Press, 2008). c. Asas Laras

Pedoman laras dalam hukum baku digunakan secara cerdik dalam menyelesaikan pergulatan standar yang substansial, dengan tujuan agar afiliasi yang bersangkutan dan kelompok masyarakat asli merasa puas. Penggunaan pendekatan rule of amicability dilakukan dengan mempertimbangkan tempat, waktu, dan kondisi (pedesaan, kala, patra) dengan tujuan agar pilihan-pilihan pada pertanyaan standar dirasakan oleh perkumpulan dan daerah setempat.

Kapasitas Kepala pedesaan sebagai kompromi pada dasarnya adalah orang tengah yang memiliki komunitas informal perantara dan arbiter yang sah. Pada umumnya batas ini dikenal dengan istilah hakim pengadilan pedesaan (dorpjustitie). Batasan kepala pedesaan sebagai kompromi sesuai dengan pedoman dalam Pasal 26 ayat (4) huruf k Undang-Undang Nomor 6 Tahun 2014 tentang pedesaan tidak dapat dipisahkan dari kenyataan yang dapat ditunjukkan bahwa pada masa lalu di tingkat pedesaan dan standar jaringan hukum telah dikenal oleh eksekutif 
Hj. Desmawaty Romli et.al, Kewenangan Kepala Desa Dalam Menyelesaikan Sengketa Masyarakat Berdasarkan Undang-Undang Desa, Halaman 17- 30

hukum. pedesaan serta eksekutif hukum adat. ${ }^{13}$

Kewenangan kades dalam menjalankan hukum di desa adalah cara untuk mengontrol dan memperbaharui masyarakat desa. Pendekatan yang sah ini dijalankan dalam penerapan penyelesaian konflik oleh Kepala desa. ${ }^{14}$

\section{B. Kekuatan Hukum dari Hasil Mediasi Penyelesaian Perselisihan}

\section{Masyarakat oleh Kepala Desa}

Gagasan penyelesaian konflik melalui perundingan musyawarah telah cukup sejak lama dikenal oleh hukum baku daerah jauh sebelum komponen gugatan diajukan oleh pemerintah perintis Belanda. ${ }^{15}$ Syafaat adalah pekerjaan untuk menentukan pertanyaan di antara pertemuanpertemuan yang mencari pemahaman bersama melalui seorang perantara yang memiliki sikap tidak memihak yang tidak memiliki atau menentukan

13 Sri Lestari Rahayu, Mulyanto, Anti Mayastuti, "Penguatan Fungsi Kepala Desa sebagai Mediator Perselisihan Masyarakat di Desa," Jurnal Yustisia, Volume 5 Nomor 2, Mei-Agustus 2016: 349.

14 Samuel Dharma Putra Nainggolan, "Kedudukan Kepala Desa sebagai Hakim Perdamaian."

${ }^{15}$ Nurnaningsih Amriani, Mediasi Alternatif Penyelesaian Sengketa Perdata di Pengadilan (Jakarta, Rajagrafindo Persada, 2012). pilihan atau tujuan pertemuan, yang merupakan tanggung jawab fasilitator demi tercapainya kesepakatan diantara para pihak dalam keadaan yang terbuka, kejujuran dan saling berbagi pendapat agar tercapainya mufakat.

Kedudukan Kades sebagai hakim kerukunan dalam menyelesaikan bentrokan yang terjadi di desa merupakan upaya diskresi/kebijakan dari lembaga eksekutif dalam mengakui penyelenggaraan pemerintahan bagi warganya. Dengan adanya diskresi ini, tidak dapat dipisahkan dari pedoman dan undangundang yang memberikan batasan dalam penerapannya ${ }^{16}$.

Kepala desa adalah tokoh daerah yang sangat dihormati oleh daerah setempat, sehingga ia memainkan peran penting dalam menyelesaikan konflik adat, terutama sebagai mediator. Mengingat Dalam Undang-Undang Nomor 6 Tahun 2014 tentang pedesaan disebutkan bahwa kepala pedesaan adalah pimpinan pemerintahan pedesaan yang mempunyai kedudukan yang setara kokoh dan definitif, hal ini dapat berkuasa dalam menyelesaikan

16 Samuel Dharma Putra Nainggolan, "Kedudukan Kepala Desa sebagai Hakim Perdamaian.” 
Hj. Desmawaty Romli et.al, Kewenangan Kepala Desa Dalam Menyelesaikan Sengketa Masyarakat Berdasarkan Undang-Undang Desa, Halaman 17- 30

tugasnya sebagai mediator yang dalam penyelesaian konflik. ${ }^{17}$

Dengan adanya mekanisme mediasi tersebut sehingga timbulnya persetujuan, maka pihak yang berkonflik menandatangani kesepakatan dan harus mendaftarkannya ke Pengadilan Negeri dalam waktu 30 hari sejak penandaan. Tindakan ini, mengingat Pasal 6 ayat (7) Undang-Undang Nomor 30 Tahun 1999 tentang Penegasan dan Tujuan Pertanyaan Pilihan, bersifat konklusif dan membatasi. Namun, jika di kemudian hari ada pihak-pihak yang keluar untuk tidak menyelesaikan kesepakatan tersebut, maka pada saat itu kesepahaman yang mereka buat meskipun telah didaftarkan ke pengadilan, sama sekali tidak memiliki kekuatan untuk eksekutorial ${ }^{18}$.

Persetujuan atau perjanjian perdamaian yang terjadi karena adanya intervensi yang telah ditegaskan dan statusnya sebagai akta kerukunan (acte van dading) mempunyai kekuatan yang

17 Sri Lestari Rahayu, Mulyanto, Anti Mayastuti, "Penguatan Fungsi Kepala Desa sebagai Mediator Perselisihan Masyarakat di Desa."

${ }^{18}$ Sri Hajati, Agus Sekarmadji, dan Sri Winarsi, Model Penyelesaian Sengketa Pertanahan Melalui Mediasi Berkepastian Hukum, Jurnal Dinamika Hukum, Volume 14, Nomor 1, 201: 40. sangat besar sebagai suatu putusan pengadilan yang mempunyai kekuatan legitimasi yang bertahan lama, maka pada saat itu pilihan kerukunan tersebut mempunyai 3 (tiga) kemampuan yang substansial. seperti membatasi dan kekuatan terakhir, kekuatan pembuktian yang luar biasa, dan kekuatan utama. Pembatasan menyimpulkan bahwa segala sesuatu yang telah diselesaikan dan dinyatakan dalam akta perdamaian dapat diselesaikan dengan dieksekusi oleh pengadilan, dengan jelas mengasumsikan salah satu majelis mengingkarinya. Sementara yang terakhir menyarankan bahwa dengan memperluas situasi dengan perjanjian non-agresi menjadi akta kerukunan, semua upaya hukum yang dilakukan oleh pertemuan-pertemuan itu telah ditutup pihak ${ }^{19}$.

Penegasan tersebut diharapkan dapat memperoleh kekuasaan yang sah dan dapat mengikat pertemuanpertemuan yang bentrok dari suatu perjanjian non agresi. Hal ini sesuai Pasal 27 Peraturan Mahkamah Agung Nomor 1 Tahun 2016 tentang Prosedur

19 Indriati Amarini, Penyelesaian Sengketa Yang Efektif dan Efisien Melalui Optimalisasi Mediasi di Pengadilan, Jurnal Kosmik Hukum, Volume 16, Nomor 2, 2016: 94. 
Hj. Desmawaty Romli et.al, Kewenangan Kepala Desa Dalam Menyelesaikan Sengketa Masyarakat Berdasarkan Undang-Undang Desa, Halaman 17- 30

Mediasi di Pengadilan yang menyatakan bahwa:

1) Jika Mediasi Secara efektif setuju, Pertemuan dengan bantuan orang Tengah diperlukan untuk merinci pengaturan yang tersusun dalam perjanjian Non agresi yang didukung oleh Pertemuan dan Perjalanan antara.

2) Dalam membantu merinci perjanjian Non agresi, Arbiter wajib menjamin bahwa perjanjian Nonagresi tidak memuat pengaturan-pengaturan yang:

a. bertentangan dengan hukum, permintaan publik, serta konvensionalitas;

b. menyakiti orang luar; atau c. tidak bisa dilaksanakan.

3) Dalam proses Mediasi ditangani oleh agen yang sah, persetujuan Kesepakatan Harmoni harus dilakukan jika ada pernyataan tertulis dari Pertemuan yang berisi kesepakatan tentang kesepakatan.

4) Para Pihak melalui Mediator dapat mengajukan perjanjian Non-agresi kepada Hakim Pemeriksa Kasus untuk diperkuat dalam Akta Kerukunan.

5) Dalam hal Pertemuan tidak perlu diperkuat dengan Akta Kerukunan dalam Perjanjian Non-Agresi, maka perjanjian Non-Agresi harus memuat pengingkaran perkara.

6) Mediator harus melaporkan dicatat sebagai hard copy pencapaian Intervensi kepada Hakim Pemeriksa Kasus dengan bergabung dalam perjanjian Non agresi.

Hal ini sesuai Pasal 1858 ayat (1) dan (2) Common Code dan Pasal 130 HIR/Pasal $154 \mathrm{RBg}$ ayat (2) dan (3) yang mengatur perjanjian nonagresi. Dalam perincian Pasal 1858 Kitab Undang-Undang Hukum Perdata dinyatakan:

a. Semua harmoni antara pertemuan memiliki kekuatan seperti pilihan juri di tahap terakhir.

b. Kerukunan tidak dapat dipertanyakan atas dasar kesalahan dalam hukum atau karena salah satu perkumpulan terluka.

Selain itu, Pasal 130 HIR/154

RBg ayat (2) dan (3) menyatakan:

a. Seandainya terjadi kompromi seperti itu, maka pada saat itu, pada jam pertemuan, dibuat suatu akta yang dengannya kedua pemain itu diperlukan untuk memenuhi kesepahaman yang telah dibuat, maka pada saat itulah surat (akta) itu akan dibuat. substansial 
Hj. Desmawaty Romli et.al, Kewenangan Kepala Desa Dalam Menyelesaikan Sengketa Masyarakat Berdasarkan Undang-Undang Desa, Halaman 17- 30

dan akan dilakukan sebagai pilihan otoritas yang ditunjuk bersama.

b. Tentang pilihan seperti itu tidak bisa ditanyakan banding.

Kedua pasal tersebut pada intinya menjelaskan bahwa pilihan harmoni memiliki kekuatan yang sama dengan pilihan hakim (pengadilan) pada tahap terakhir, sehingga memiliki kekuatan keaslian yang sangat tahan lama, dan terhadap pilihan ini tidak ada daya pikat atau kasasi. Oleh karena itu, akta kerukunan yang ditegaskan dalam pilihan kerukunan yang telah diperiksa di bawah pengawasan majelis hakim memiliki kepastian hukum yang sah seperti halnya pilihan standar yang memiliki kekuatan hukum super tahan lama, khususnya kekuatan membatasi dan terakhir, kekuatan pembuktian yang luar biasa, dan kekuasaan utama.

\section{KESIMPULAN}

Penyelesaian sengketa secara alternatif penyelesaian yang dilakukan desa merupakan bentuk kemandirian dan keistimewa desa. Kepala Desa mempunyai kewenangan sebagai hakim perdamaian dalam upaya memberikan pelayanan publik bagi warga desa. Penyelesaian sengketa dengan cara non litigasi dalam Common law dikenal dengan Elective Question Goal, sedangkan dalam hukum pidana dikenal Elective Debate Goal dengan mediasi penal. Apabila tercapai kata sepakat dalam upaya penyelesaian sengketa tercapainya perdamaian, kemudian, pada saat itu, perkumpulan-perkumpulan itu menyetujui pengaturan itu dan harus mendaftarkannya ke Pengadilan Wilayah dalam waktu 30 hari sejak penandaan, sehingga memiliki kekuatan hukum tetap.

\section{DAFTAR PUSTAKA}

Bambang Sugeng, Penanganan Konflik Sosial, Bandung: Pusat Bencana dan Pengungsi (PUSKASI) STKS, 2011.

Darsono Wisadirana, Sosiologi Pedesaan Kajian Kultural dan Struktural Masyarakat

Pedesaan, Malang: UMM Press, 2005.

I Nyoman Sirtha, Aspek Hukum dalam Konflik Adat di Bali, Bali: Udayana University Press, 2008. Indriati Amarini, Penyelesaian Sengketa Yang Efektif dan Efisien Melalui Optimalisasi Mediasi di Pengadilan, Jurnal Kosmik Hukum, Volume 16, Nomor 2, 2016: 94. 
Hj. Desmawaty Romli et.al, Kewenangan Kepala Desa Dalam Menyelesaikan Sengketa Masyarakat Berdasarkan Undang-Undang Desa, Halaman 17- 30

Jhoni Ibrahim, Teori \& Metode Penelitian Hukum Normatif, Malang : Bayu Media, 2005.

Moh. Jamin, Anti Mayastuti, Mulyanto "Pemberdayaan Fungsi Kepala Desa sebagai Mediator Penyelesaian Sengketa Pasca Undang-Undang Nomor 6 Tahun 2014 tentang Desa", Jurnal Parental Hukum dan Budaya, Volume 3 Nomor 2, Oktober 2015: 55.

Nurnaningsih Amriani, Mediasi Alternatif Penyelesaian Sengketa Perdata di Pengadilan, Jakarta, Rajagrafindo Persada, 2012.

Peter Mahmud, Penelitian Hukum, Jakarta: Kencana Pradana Media Grup, 2008.

Rachmadi Usman, Pilihan Penyelesaian Sengketa di Luar Pengadilan, Bandung: PT. Citra Aditya Bakti, 2003.

Samuel Dharma Putra Nainggolan, "Kedudukan Kepala Desa sebagai Hakim Perdamaian," Jurnal UBELAJ, Volume 3 Nomor 1, April 2018: 59

Soerjono Soekanto, Sosiologi Suatu Pengantar, Jakarta: PT. Raja Grafindo Persada, 2006.

Sri Hajati, Agus Sekarmadji, dan Sri Winarsi, Model Penyelesaian Sengketa Pertanahan Melalui Mediasi Berkepastian Hukum, Jurnal Dinamika Hukum, Volume 14, Nomor 1, 201: 40.

Sri Lestari Rahayu, Mulyanto, Anti Mayastuti, "Penguatan Fungsi Kepala Desa sebagai Mediator Perselisihan Masyarakat di
Desa," Jurnal Yustisia, Volume 5 Nomor 2, Mei-Agustus 2016: 349.

Wiryono Surachmand, Pengantar Penelitian Ilmiah, Bandung: Tarsio, 1991. 